\title{
The Modification of Management Cost of Products and Promotion Education in UMKM Cemandi Sidoarjo
}

\author{
Dwi Suhartini*, Oryza Tannar, Muhammad Nugraha Eka Wardana, Galuh Tiaramurti \\ Economic and Businesses Faculty, Universitas Pembangunan Nasional “Veteran” Jawa Timur, Indonesia
}

${ }^{*}$ Corresponding author

E-mail:

dwisuhartini.ak@upnja-

tim.ac.id

\begin{abstract}
Micro, Small, and Medium Enterprises (MSMEs) are informal business organizations that are the driving force of the national economy. The government pays special attention to the development of MSMEs by fostering a conducive business climate environment, providing access to productive resources, strengthening entrepreneurship, and increasing its competitiveness. The purpose of this community service activity is to provide training and assistance to groups of UMKM entrepreneurs in the Sedati sub-district, Sidoarjo regency that produces food and beverages. The problem that is often faced by the MSME sector is the problem of determining the cost of goods, if the determination of the cost of goods is not accurate, it will affect the determination of the selling price. For this reason, training and mentoring is necessary so that entrepreneurs have the knowledge and skills in calculating the cost of production as a basis for determining the selling price. Also, there were problems related to the difficulty of marketing products. This is due to limited access to information and low human resource skills. The results of this service provide evidence that MSME entrepreneurs have not included components of direct labor costs and overhead costs in the production process, such as employee salaries as direct labor costs and overhead costs, such as electricity costs, water costs, telephone costs, equipment depreciation costs. For this reason, MSME entrepreneurs are given training and assistance on how to calculate production costs using the full costing method so that the calculation of production costs is more accurate. The cost of goods obtained will be used as the basis for determining the selling price. Also, they are given training and assistance on digital marketing to provide education and improve skills on how to market their products online so that MSME products are more widely known and can answer business opportunities in the era of industrial revolution 4.0 .
\end{abstract}

Keywords: MSME, Cost of Production, Cost of Goods, and Marketing

\section{Introduction}

The State of Indonesia pays special attention to the development of Micro, Small, and Medium Enterprises (MSMEs) by fostering a conducive business climate environment, providing access to productive resources, strengthening entrepreneurship, and increasing competitiveness. MSMEs are the backbone of the East Java economy. This can be seen from the empirical facts in the field. Among them is the performance of the processing industry in the last five years which has contributed to an increasing national income, from 19.91 percent in 2013 to 21.70 percent in 2017. (LKPJ Jatim, 2017). The problems that are often faced by the MSME sector include the problem of determining the cost of goods and selling prices. The cost of goods manufactured (HPP) consists of raw material costs, direct labor, and overhead costs. However, the reality is that MSME entrepreneurs only charge for materials in calculating the HPP of their products, so that it is inaccurate and will have an impact on determining the selling price. The reasoning that underlies this problem is that the cost of goods is the basis for determining the selling price of the product. The reason is that the value of the cost of goods is too low it will be detrimental to the sustainability of the

\section{How to cite:}

Suhartini, D., Tannar, O., Wardana, M. N. E., \& Tiaramurti, G. (2021). The modification of management cost of products and promotion education in UMKM Cemandi Sidoarjo. $5^{\text {th }}$ International Seminar of Research Month 2020. NST

Proceedings. pages 325-333. doi: 10.11594/ nstp.2021.0950 
business and conversely if it is too high it will be detrimental to the buyer. For that, it is necessary to conduct training for MSME entrepreneurs in calculating the cost of production as the basis for determining the selling price.

\section{Situation analysis}

UMKM entrepreneurs are members of the Sri Rezeki Women's Cooperative in Cemandi Village, Sedati District, Sidoarjo Regency. The types of UMKM businesses include food and beverages, handicrafts or handmade, grocery stores, boarding houses, then only UMKM will be selected in the industrial sector. The number of considerations is more than the type of trading and service business. The calculation of the cost of production on MSME products needs to be done so as not to experience losses and also as a tool to monitor the realization of product costs. According to Mulyadi (2012) states that determining the cost of goods manufactured is a method of calculating the cost of goods starting from production until the goods are finished and ready for sale, where the cost of goods manufactured is one of the most important elements in determining the cost of goods sold.

\section{Partner attention}

The strategic problem faced by MSMEs in Cemandi Village, Sedati District, Sidoarjo Regency is the lack of accuracy in determining the cost of goods so that it has an impact on determining the selling price. Most of them have not included the cost of electricity, water, and depreciation in the cost of goods calculation. This condition is indicated by the lack of understanding of the elements of production costs and the costs of production activities that have not been separated from household costs, especially electricity and water costs. Also, MSME players experience problems in marketing their products. For that, it is necessary to carry out training in calculating the cost of goods, selling prices, and online promotions. The training is one of the right solutions that can be done.

\section{Solution}

Based on the explanation of the partners' problems, efforts will be made to increase the knowledge and skills of MSME managers in determining the cost of goods and selling prices. Also, this service activity is directed at increasing the ability of MSME managers to market products without borders with an online system. In simple terms, the formulation of the problem-solving paradigm model is as follows.

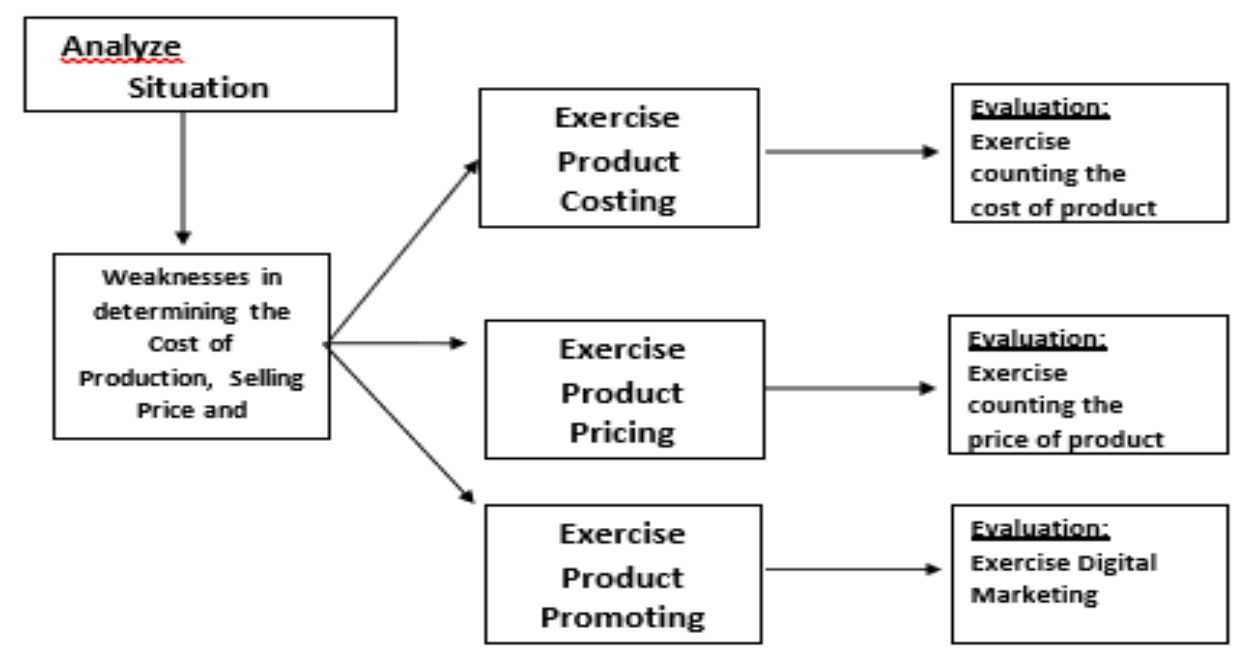

Figure 1. The formulation of the problem-solving paradigm model 


\section{Theory Concept}

Cost of goods sold

The calculation of the cost of production on UMKM products needs special attention so that in determining there are no distorted costs so that MSMEs are not wrong in determining the selling price which subsequently does not experience losses. Mulyadi (2012) states that the determination of the cost of goods manufactured is a method of calculating the cost of goods starting from production until the goods are finished and ready to be sold, where the cost of goods manufactured is one of the most important elements in determining the cost of goods sold.

Also, Supriyono (2011) defines the cost or cost of goods as the amount that can be measured in units of money in the form of cash paid, or the value of other assets that can be delivered or sacrificed, or services rendered or sacrificed, or debt incurred or additional. capital in the context of owning goods or services needed by the company, both from the past (acquisition costs that have occurred) or in the future (acquisition costs that will occur), while Hansen and Mowen (2001) explain that the cost of production (cost of production) goods manufactured) reflects the total cost of goods completed during the period. Costs that are only charged to goods completed are manufacturing costs of direct materials, direct labor, and overhead.

Based on the expert's understanding, it can be interpreted that the cost of goods manufactured is the total cost used to produce a product during a certain period, either as direct costs or indirect costs. The determination of the cost of goods manufactured is a very important factor in determining the selling price.

\section{The Elements of Cost of Production}

Hansen and Mowen (2001) distinguish in three ways, namely:

\section{a. Direct Material}

Direct materials are materials that can be traced directly to the goods or services being produced. The cost of this material can be charged directly to the product because physical observations can be used to measure the quantity consumed by each product.

b. Direct labor

Direct labor is labor that can be traced directly to the goods or services being produced. Physical observations can be used to measure the number of employees involved in producing a product and service.

c. Overhead

All production costs - other than direct materials and direct labor - are grouped under one category called overhead.

Also, Carter (2012) differentiates these costs, as follows:

1. Direct material cost

The definition of direct raw material costs is the cost for materials that are directly and easily identified with finished goods. Examples include tobacco for cigarette companies and wood for furniture companies.

2. Direct labor costs

The definition of direct labor costs is labor who works directly on the production process or who can be identified directly with finished goods. Examples include direct labor, namely cigarette rollers in cigarette companies and carpenters in furniture companies.

3. Factory overhead costs

The definition of overhead costs is factory costs other than raw materials and direct labor. This cost cannot be identified directly with the goods the company produces.

The example is

a. Supporting materials or indirect materials such as factory equipment, paints, carving machines in furniture companies. 
b. Indirect labor is labor that cannot be directly linked to the goods produced, such as a foreman's salary.

c. Repair and maintenance (repair and maintenance).

d. Electricity, telephone, and water costs.

Purpose of Cost of Production

Mulyadi (2012) states that:

a. Production cost is one of the data that is considered in addition to non-production data in determining the selling price of the product being marketed.

b. To monitor the realization of production costs.

c. Calculate the company's gross profit and loss for a certain period.

d. Determining the prices of in-process products and finished products that are shed on the balance sheet.

Method of Determining Cost of Production

According to Daljono (2011), there are two methods in determining the cost of goods, namely as follows:

1. Full costing

Is a method of determining the cost of the product by including all variable and fixed costs for the product. It is described as follows:

Raw material cost $\mathrm{xxx}$

Direct labor costs $\mathrm{xxx}$

Variable factory overhead costs $\mathrm{xxx}$

Fixed factory overhead costs $\mathrm{xxx}$

Cost of production $\mathrm{xxx}$

2. Variable Costing

Is a calculation of the cost of a product that only includes variable production costs. Costs that are fixed to the product (BOP not fixed) are included as period costs. It is described as follows:

Raw material cost $\mathrm{xxx}$

Direct labor costs $\mathrm{xxx}$

Variable factory overhead costs $\mathrm{xxx}$

Cost of production $\mathrm{xxx}$

Cost behavior about changes in the volume of activity.

According to Carter (2012), costs can be classified into 3 classifications of each expense, namely:

1) Fixed costs are costs incurred by the company in constant conditions and generally do not change even though there is an increase or decrease in the number of goods and/or services produced, for example

- Fixed asset depreciation expense

- Rental Costs

- Salary expense

- Insurance fee

- Costs that are not affected by sales volume

2) Variable costs (variable costs) are costs incurred by the company in a variable (proportional) manner which is based on changes in the number of products produced, for example:

- Cost of raw materials

- Direct labor costs 
- $\quad$ Equipment costs

3) Semi variable cost (semivariable cost) is a cost whose amount is affected by the volume of company activities but not proportionally, has elements of fixed costs and variable costs, for example:

- Electricity, water, and telephone bills

- Machine repair costs

- The cost of maintaining office equipment

\section{Cost of Goods Sold}

An important factor of special concern for MSMEs is to determine the selling price is cost. In determining the selling price, the cost factor is used as the lower limit because in a fair condition the selling price must be able to cover all costs related to the product or service and be able to generate the expected profit. It is assumed that the selling price set must be higher than the total costs incurred to be profitable for the company. Management must be able to reduce and control costs so that the cost structure remains low so that the selling price of the products offered can be reduced.

Hansen and Mowen (2001) define "The selling price is the monetary amount charged by a business unit to buyers or customers for goods or services sold or delivered", explained Mulyadi (2012) that in principle, the selling price must be able to cover the full cost. coupled with a reasonable profit. The selling price is equal to production cost plus Mark-up.

\section{Selling Price Setting}

The selling price-setting method according to Mulyadi (2012) is as follows:

1) Normal Pricing.

Under normal circumstances, the selling price is determined at full cost and added to the expected profit. The determination of the normal selling price is known as cost-plus pricing, full cost estimation can be done with two approaches, namely full costing, and variable costing

2) Cost Type Contract.

A contract for the manufacture of a product or service in which the buyer agrees to buy the product or service at the total cost incurred by the producer plus the profit which is calculated as a certain percentage of the total actual cost.

3) Determining the Special-Order Selling Price (special order pricing).

Orders received by the company outside of the company's regular orders. Regular order is

an order that is tasked with covering all fixed costs that will occur in the fiscal year.

4) Determination of the Selling Price or Time and Materials.

Determining the selling price and materials is cost-plus pricing. The selling price is determined at the selling price per fruit plus the expected profit.

\section{Material and Methods}

The solution offered to solve the problem consists of the following stages:

a. The framework for solving MSME problems to be solved is an effort to increase knowledge and skills in determining the cost of goods and selling prices as well as digital marketing. The formulation of the problem-solving model is as follows:

b. The target is the MSME manager who is also a member of the Cemandi Village Women's Cooperative, Sedati District, Sidoarjo Regency. For the sake of community service and availability of facilities and infrastructure, 20 UMKM players were taken.

c. Approach Method Training is held with lectures, questions and answers, and practice. This method is used to convey material about determining the cost of the product and the selling price of the product. Determination of the cost of goods by comparing the calculation of the 
product itself with the calculation that has been done yourself and compared with the calculation with full hosting.

d. The design of the evaluation of the training results is carried out by staying in touch with the WA group. This was done to limit direct interactions in the conditions of the COVID-19 pandemic. Assistance as a form of evaluation was carried out offline while maintaining health protocols.

\section{Result and Discussion}

This service activity was carried out at the Association of MSME Entrepreneurs, Sedati District, Sidoarjo, which has 60 members, but the training was attended by 20 MSME entrepreneurs because they were trying to meet the Covid19 health protocol. The resulting products, such as donuts, Bolen cakes, pastries, honey, black onions, mixed ice, sinom drinks, sambel klothok, and dumplings.

The training for calculating basic prices was held on August 28, 2020, at the meeting building of the Sedati District, Sidoarjo Regency. This activity was attended by the chairman of the association and 20 members of the association. The material was delivered by Dwi Suhartini, here is the documentation of when the material was presented.

Vermicompost which is added by Streptomyces microorganisms is the result of decomposition of organic materials that are decomposed (overhauled) by earthworms plus Streptomyces microorganisms, the result of which is an organic fertilizer with biological sense, can provide nutrients needed by plants for plant growth and development.

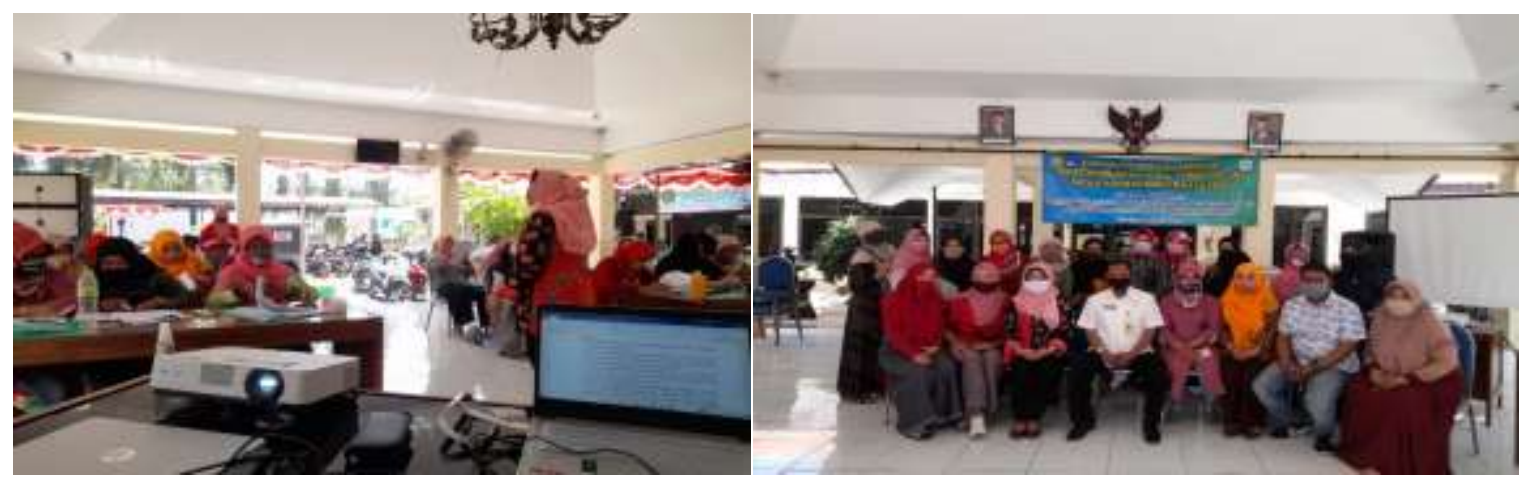

Figure 2. Training of association of MSME entrepreneurs

The results of the analysis prove that the determination of the cost of products is not quite right so that it affects the determination of the selling price. The facts in the field prove that the cost of goods manufactured components have not included labor costs and overhead costs. They do not realize that the labor cost must be taken into account, even though labor is itself, but in business, it must be taken into account. Likewise, with overhead components, such as electricity and water costs. These costs are often overlooked because they are mixed with the costs of meeting the needs of the family. This is because production activities are integrated into family activities. Also, equipment depreciation costs have not been considered.Training is provided by providing knowledge and skills to MSME entrepreneurs by directly practicing calculating product costs by comparing their own calculations with calculations based on full costing.

An example of a case raised from the results of the training is a product of $\mathrm{Bu}$ Ika as a culinary entrepreneur with Klothok MbokKayah. The following is presented in the Table. 1 comparison of the calculation of production costs before training with during training with the full costing method. The results of calculating production costs before training do not include labor costs and 
overhead costs. Cost per unit cost Rp. 7,450, - and after using full costing, the unit cost is Rp. 10,470 . The selling price is set at Rp. 15,000 , taking into account the prices of competitors.

Table 1. Comparison of the calculation of sambel klothok products per 10 packaging bottles

\begin{tabular}{|c|c|c|c|}
\hline No & Cost name & $\begin{array}{l}\text { Base price before train- } \\
\text { ing (Rp) }\end{array}$ & Full costing (Rp) \\
\hline \multirow[t]{10}{*}{1} & Bahan: & & \\
\hline & klotok fish $1 \mathrm{~kg}$ & 35.000 & 35.000 \\
\hline & Small chilies & 5.000 & 5.000 \\
\hline & Tomato & 2.000 & 2.000 \\
\hline & Oil & 3.000 & 3.000 \\
\hline & Chili & 2.500 & 2.500 \\
\hline & Sticker & 5.000 & 5.000 \\
\hline & Packaging bottles & 20.000 & 20.000 \\
\hline & LPG & 1.000 & 1.000 \\
\hline & Masking tape & 1.000 & 1.000 \\
\hline \multirow[t]{2}{*}{2} & Labor: & & \\
\hline & Salary of workers & & 25.000 \\
\hline \multirow[t]{8}{*}{3} & Overhead costs: & & \\
\hline & Electricity cost & & 1.700 \\
\hline & Water costs & & 1.000 \\
\hline & Stove depreciation cost & & 2.500 \\
\hline & Total & 74.500 & 104.700 \\
\hline & 10 bottles & 7.450 & 10.470 \\
\hline & Selling price / bottle & 15.000 & 15.000 \\
\hline & Margin/botol & 7.550 & 4.530 \\
\hline
\end{tabular}

Source: Bu Ika production cost data

Based on the comparison of the calculation of production costs in the case raised, it can be analyzed that the cost of goods determination using the full cost method is higher than the previous calculation of product costs. This indicates that labor and overhead costs have not been included. This fact concludes that errors in determining the production cost of a product will have an impact on the determination of its selling price, as stated by Mrs. Ika that her business has received a margin of around $50 \%$, but in reality, it only gets a margin of $30 \%$ after being calculated by full hosting.

This is because Mrs. Ika has not included labor costs and overhead costs, so the margins appear large even though they are not as large as imagined so that there are often MSME statements that their business is difficult to develop. This ensures that MSME actors do not just take their margins, but also take their capital for their personal needs. The problems experienced by Mrs. Ika were also experienced by several UMKM entrepreneurs who participated in the training, such as Mrs. Erna is a UMKM entrepreneur who owns UD Donat Kampoengan. Mrs. Erna has not included direct labor costs and overhead costs, so she thinks that her business has provided a margin. However, after calculating the full costing margin, it was received very minimal, only around $28 \%$.

This is what underlies the idea that inaccurate determination of the cost of goods will affect the determination of the selling price and the selling price that is too low will have an impact on business losses. The following describes the production costs for making 80 donuts. 
Table 2. Comparison of Kampoengan Donut product calculation per 80 donuts

\begin{tabular}{llcc}
\hline No & Cost name & $\begin{array}{l}\text { Base price before training } \\
\text { (Rp) }\end{array}$ & Full costing (Rp) \\
\hline $\mathbf{1}$ & Material: & 13.000 & \\
& Wheat 1 kg & 4.000 & 13.000 \\
& Sugar 200 gr & 6.000 & 4.000 \\
4 Eggs & 2.000 & 6.000 \\
Milk 4 sdm & 9.000 & 2.000 \\
Butter 200 gr & 20.000 & 9.000 \\
Buttercream 1 kg & 25.000 & 20.000 \\
Chocolate messes 250 gr & 10.000 & 25.000 \\
Oil 1 lt & & 10.000 \\
& & \\
$\mathbf{2}$ & Labor: & 50.000 \\
& Salary of 2 workers & & \\
& & \\
Overhead costs: & & 2.000 \\
Stove depreciation cost & & 2.000 \\
Fryer depreciation cost & 89.000 & 143.000 \\
Total & 1.112 & 1.787 \\
Donuts 80 pcs & 2.500 & 713 \\
\hline Selling price/donut & 1.388 & \\
Margin/donat & &
\end{tabular}

Source: Mrs. Erna's production cost data

The training evaluation design is carried out by always communicating through the UMKM WA Group, the aim is to see the progress of the implementation of the training results. This was also done to limit direct interactions with MSME entrepreneurs during the Covid 19 pandemic. Evaluations were also carried out offline while maintaining health protocols.

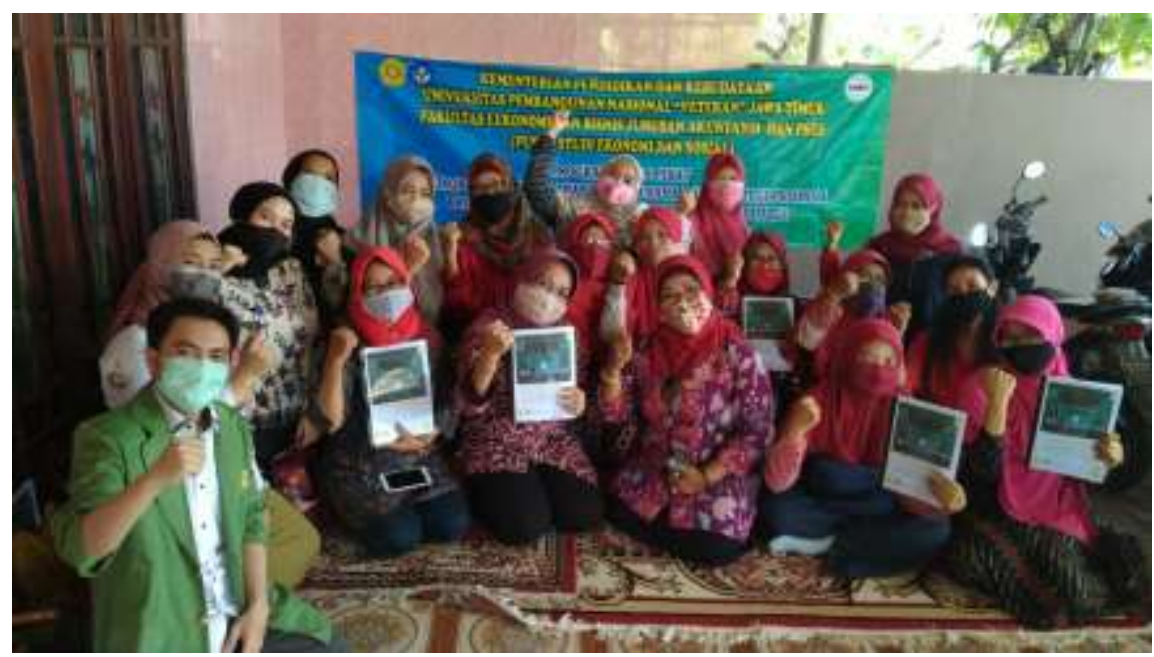

Figure 3. Training evaluation of association of MSME entrepreneurs

The results of group and offline discussions proved that not all of the 20 entrepreneurs who participated in the training implemented full-posting calculations for their products. Only the honey and black onion entrepreneurs have implemented it, while the donuts, sponge cake, mixed 
ice, sinom, and klothok sambel entrepreneurs are still gradually learning to apply. They have not dared to raise prices, because they still consider competitor prices and maintain consumer loyalty.

The results of this service program are supported by research conducted by Anita and Susanti (2016) which states that the full costing method reflects all the resources used. Likewise, the results of the dedication carried out by Maghfirah and Syam (2016) prove that obtaining the cost of goods manufactured using the full hosting method is a better method.

\section{Conclusion}

1. Comparison of the cost of goods manufactured according to the two calculation methods shows different results.

2. Costs involved in the production process include raw material costs, direct labor, and factory overhead costs (electricity costs, depreciation costs, water usage costs)

3. The use of the full costing method will show a more accurate result of the cost of goods manufactured which will result in the acquisition of the selling price so that the selling price of the product will be sold at a fair price.

4. Errors in calculating the cost of goods manufactured to result in errors in setting the selling price and have an impact on errors in decision making, in management errors in decision making can fail in a business.

\section{Acknowledgment}

The author would like to thank UPN "Veteran" Jawa Timur, the Leader of UMKM Cemandi, and the person of them. And we would like to thank the Team of Lecturer in Accounting, Economic and Businesses Faculty to be a consultant in Exercise cost of Product.

\section{References}

Anita, D., \& Susanti, D. (2016). Analisis perhitungan harga pokok produksi tahu dan susu kedelai dengan metode full costing dan variable costing pada industri kecil (Studi kasus UKM Tahu Putih "XX" Pekanbaru). KURS, 1(1), 1-10.

Carter. (2012). Akuntansi biaya (Edisi 13; B. 1, Ed.). Jakarta: Salemba Empat.

Daljono (2011). Akuntansi biaya penentuan harga pokok dan pengendalian. Edisi ketiga, Badan Penerbit Universitas Diponegoro, Semarang.

Hansen \& Mowen. (2001). Akuntansi manajemen (Edisi 4). Jakarta: Penerbit Salemba Empat.

LKPJ Jatim. (2017). Laporan keterangan pertanggungjawaban akhir tahun Jawa Timur Tahun Anggaran 2017. Retrieved from: http://jatimprov.go.id/read/berita.

Maghfirah, M., \& Syam, B. Z. F. (2016). Analisis perhitungan harga pokok produksi dengan penerapan metode full costing pada UMKM Kota Banda Aceh. Jurnal Ilmiah Mahasiswa Ekonomi Akuntansi (JIMEKA), 1, 59-70.

Mulyadi. (2012). Akuntansi biaya. Edisi ke-5. Cetakan Kesebelas. Yogyakarta: STIM.

Supriyono (2011). Akuntansi biaya pengumpulan biaya dan penentuan harga pokok, Buku 1 Edisi 2. Yogyakarta: BPFE. 